\title{
A Survey of Nigeria's Conspiracy Response Theories on the COVID-19 Pandemic with its Effect on National Development
}

\author{
Henry Marcus Garba \\ Africa International University, Department of Historical Studies \\ DOI: 10.29322/IJSRP.10.12.2020.p10892 \\ http://dx.doi.org/10.29322/IJSRP.10.12.2020.p10892
}

\begin{abstract}
The approach of the Nigerian government concerning the COVID-19 pandemic has drawn public criticism by the citizens, especially in the media. The outbreak of the COVID-19 epidemic has brought a diverse, responsive approach among different nations. Since the disease outbreak, measures have been taken to curb the spread of the virus by government and private organizations in Nigeria. This study explores the different concerns that Nigerians have raised against the government in responding to the pandemic. Through different media platforms, a significant number of Nigerians accused the government of a fraudulent approach to the plague, arguing that its consequences are enormous, especially on national development. This study is qualitative, using an anecdotal method to explore the viewpoint of Nigerians on the different measures that the government has adopted to win the global war against the COVID-19 virus. As the pandemic continues to impact the global society, Nigeria is not exempted. The question, therefore, is, how has the Nigerian government responded to the outbreak? What impact has those approaches made in the lives of the ordinary citizen? How confident are the Nigerian populace on the government that they duly elected to safeguard them in times of threats and anxiety? Would the aftermath of the outbreak strengthen or further crumble the fragile infrastructural development of Nigeria? These glaring concerns ignite the passion for this synopsis.
\end{abstract}

Index Terms- Nigeria, Survey, Conspiracy Theories, COVID-19, Response, National Development

\section{INTRODUCTION}

$\mathrm{T}$ he Nigerian government has always been accused of taking advantage of the people it is supposed to protect (Olabode, 2018, p. 116). Many of the citizens do not trust the political elite, which has grossly affected the response of individuals and communities concerning the spread of the COVID-19 pandemic. Nigeria has the highest population in Africa, with one of the fastest-growing economies in the continent (Vinson, 2017, p. 5). Before the COVID-19 outbreak, the Nigerian system of governance has received widespread criticism by Nigerians, primarily through media use. Through the media, citizens are empowered and feel engaged with the government on silent issues. Again, the media, especially social media, has often been the first to break the news of corruption, misgovernance, and social ills in the society before the mainstream media because people feel free to question and criticize the government's actions and politics without the need for an intermediary (Akpojivi, 2018, p. 133).

Consequently, some Nigerian political elite has demonstrated dissatisfaction and displeasure in the media because of its success in uncovering corruption (Junior, 2013, p. 131). As a result, the power of the media has been challenged as policies and bills have been made in an attempt to criminalize the use of the media as a means of criticizing the government (Nigerians React To President Buhari's Speech On Covid-19 - YouTube, n.d.). However, Nigerians had a national call to reject these bills and policies propagated by the Nigerian senate (Chiefe, 2020).

Meanwhile, the Nigerian society is comprised of diverse social clusters. These different groups consist of the home, school, various religious, ethnic, political, and otherwise, groups, government, and media, all making up society (Okorie et al., 2016, p. 204). All of these groups help shape the moral and patriotic behaviors of members of the community; they also help contribute to the sound value system and the nation's growth and development (Okorie et al., 2016, p. 204).

Abreast, the media has been the watchdog of bad governance in Nigeria. It has also been the means that Nigerians get at the government and hold political office holders accountable (Omotoso \& Kehinde, 2016, p. 80). Accordingly, the social media agenda-setting mode is a means that good and bad governance is acknowledged. Through the media, the public has less dependent on government and journalists who sometimes are closely aligned for information (Olabode, 2018, p. 127). Thus, through the media, citizens cast a spotlight on government malfeasance and serve as a force for accountability and challenge the legitimacy of those in power (Fitch, 2013, p. 415). Hence, this study explores the influx of information through the media, which challenges the government response to the COVID-19 pandemic. Thus, many Nigerians have so much dependence on the media as its source of information, and it is such mediums that influence the decisions of the average citizenry. For many, the diverse media platforms are set up to address the challenges of governance and bridge the existing gaps between the government and the governed (H, 2017, p. 56).

Meanwhile, the concerns raised in different media platforms about the government response to the COVID-19 pandemic have drawn criticism by the citizens, affecting Nigeria's moral, social, and economic stability. Similarly, the outcome of the critique could leave devastating results and the disruption of national peace 
and unity of Nigeria; hence, this study is essential. It explores the concerns of the ordinary Nigerian who may not have the opportunity to be heard through other formal means.

\section{THE COVID-19 PANDEMIC AND THE NIGERIAN SOCIETY}

The outbreak of COVID-19 and its declaration as a global pandemic by the World Health Organization (WHO) has raised concerns, fear, and angst. Indeed, people's social lives have been shattered due to the enforcement of social distancing and lockdown as preventive measures, more so that economic hardship had grown (WHO Director-General's Opening Remarks at the Media Briefing on COVID-19 - 11 March 2020, 2020). What the world experience, as reported by media channels, is disheartening. There is the danger of economic stalking, threat of violence, and increased lawlessness. These concerns are the result of anxiety and uncertainty of what tomorrow might be. While social life is disrupted, hospitals and health workers seemed overwhelmed with the influx of possible viruses (Lennox, 2020).

In Nigeria, people appeared to be dying not because of the infection but because the attention of medical personnel turned to COVID-19 with little attention given to other ailments. Also, the Nigerian government's medical infrastructure is porous, as lamented by Nigeria's secretary to the federation (Elumoye \& Okocha, 2020). Similarly, it is suspected that every medical issue is COVID-19 related as medical personnel seemed to turn patients with other illnesses, declaring them victims of the pandemic. Recently, the secretary to the Government of the Federation (SGF), Boss Mustapha, expressed concern about reports received on medical institutions refusing to accept patients with other diseases over the fear of COVID-19 (Owolabi, 2020). The SGF submitted that the refusal to treat patients with different ailments had resulted in several unfortunate fatalities, which has led to more deaths amidst the war against the pandemic (Owolabi, 2020).

The impact of the pandemic is affecting the healthcare of non-COVID-19 cases, more so that medical personnel expressed fear of the contagion, which has resulted in turning patients away from hospitals (Adeboyejo, 2020). There is a rising concern about hunger and economic hardship. As alluded, it is not the COVID19 virus that will kill people, but starvation and fear because many Nigerians survived on the small and medium industries (Idris, 2020).

COVID-19 is a virus discovered in China, which has spread rapidly to nations around the world. The disease has claimed lives and continues to do without a permanent solution. The spread of the virus has challenged the global society to reawaken the quest for medicine (Gate, 2020). Today, the response to the infectious disease (COVID-19) accepts intellectual, religious, and political interests among nations, people, and societies (Warah, 2020).

Consequently, the aftermath of the pandemic could record the emergence of new powers and interests and could open new economic borders and allegiance (Mahbubani, 2020). While the global community is all in the fight against the virus, Africa is not left behind. The pandemic has challenged the infrastructures and governments of many African nations. COVID-19 has unraveled the weakness of countries and brought some African nations into the limelight in the effort to impact society (Denton, 2020).

For instance, while the world was struggling for medical supplies and how to manage the virus, Madagascar, a small island in the
African continent, developed a traditional medicine that drew the attention of the global society. Accordingly, the bold step and support that the government has given to medical research have pride-lifted Madagascar. Such medical discovery has attracted the commendation of WHO, which has also brought Africa to the limelight of the war against the pandemic (AfricaNews, 2020). However, in Nigeria, this development has raised concern about what role a strong economic and human resource nation like Nigeria is playing in the global scene on the war on COVID-19 (Alfa Shaban, 2020).

Meanwhile, different African governments, including Nigeria, turned to Madagascar for an alternative traditional cure for the virus. (Ekonde, 2020). These realities have challenged the Nigerian populace to cry out on the ineffectual role with great potentiality in the lead against the pandemic. This paper explores the response of Nigerians and their dissatisfaction with government responses against the fight on the COVID-19 virus. The study is conducted based on four questions: First, what is the people's view on the government approach to COVID-19? Second, how do people perceive government response to the pandemic? Third, what possible impact of government response to COVID-19 is to the development of Nigeria. Finally, the study examines people's suggestions on what the government ought to do at the COVID-19 outbreak?

\section{GOVERNMENT RESPONSE TO THE COVID-19 PANDEMIC}

A sampled response of different media platforms showed that most Nigerian populace described the Nigerian government approach to the COVID-19 as inadequate. For instance, Campbell and McCaslin submit that since the pandemic outbreak, Nigeria had recorded a low impact, which could be due to the low level of testing (Cambell \& McCaslin, 2020). The government had adopted the global measures of social distancing, lockdown, stay at home, and the avoidance of social and large gatherings; nevertheless, the enforcement of these measures were described as epileptic. The impact of the virus was twofold; on the one hand, the elites were primarily affected due to their abroad travel. On the other hand, the lockdown profoundly impacted the poor, partly due to Nigeria's low economic standard. Foremost, a day without work means a day without food (Avenue, 2020). Many who depended on the daily income for their livelihood found it challenging to obey government instructions. Other measures that the government put in place to fight the pandemic included initiating isolation centers in different states of the federation, support, and donations by individuals, non-governmental organizations, and the private sectors (Unah, 2020).

There was also the sharing of palliatives to most needy Nigerians, revising medical incentives for health workers, and many more to fight coronavirus. For instance, the Kaduna State government reviewed the salary income of COVID-19 health workers whom the governor described as the most vulnerable of 
the pandemic. ${ }^{1}$ There were also economic measures that the Nigerian government adopted to cushion the pain the virus inflicted on the populace (INSIGHT, 2020). Some of the actions that the government undertook included the reduction of fuel prices ("Why Nigeria reduce fuel price from N145," 2020). There was also the adoption of new procedures by the central bank to tackle the economic impact of the pandemic, which consisted of the establishment of fund support to the country's economy, which targeted household and micro and small enterprises, and reduction of the interest rate (Nigeria - KPMG Global, 2020).

\section{THEORIES OF NIGERIA'S CONSPIRACY RESPONSE TO THE COVID-19 PANDEMIC}

While the spread of COVID-19 continues to impact society from different perspectives, the outcome of this exploration alludes that many Nigerians downplay the effort of the government. Notably, a significant number of media respondents argue that almost every measure that the government had taken seemed to be a conspiracy, propaganda, and the politics of the elite. Some contend that though the government had announced the reduction of fuel, many filling stations, apart from government-approved filling stations like the Nigerian National Petroleum Company (NNPC), are unwilling to reverse to the new price. Foremost, there seems to be no government enforcement on the new pomp price (Ozugbakun, 2020). Alarmingly, after few months of fuel reduction, the government increased fuel prices; thus, it soared the hardship of the ordinary citizen. Also, the exchange rate has gone high, and the Naira had depreciated, causing more economic pain. Government financial measures seem to benefit only a few as the Naira experienced the worse devaluation in fifteen years (TVCNews, 2020).

Other areas that raised concern among Nigerians included the adopted steps taken to identify victims and generate the COVID-19 index number. The dispatching of Almajiris all over the states of the federation was described as a conspiracy to promote a political agenda (Channels Television, 2020). Also, the effort by the national assembly to pass the compulsory vaccine bill, and the models of sharing palliatives, all allude to these conspiracies. Few of the areas that this research explores include:

\section{THE CONSPIRACY OF VICTIMS INDEX GATHERING}

There was a lot of accusation on media of government measures in ascertaining victims and the daily index number. In an interview with the owner of Africa Independent Television (AIT), Raymond Dokpesi, about his COVID-19 experience, Dokpesi appreciated all those involved in the fight against the pandemic yet expressed concern and doubt about the virus in Nigeria. Dokpesi alleged that:

He still needed to be educated about the difference between COVID-19, a virus, and mosquito parasite, asserting that every

1 "Kaduna Government to Pay Daily Allowance to COVID-19Nigeria - The Guardian Nigeria News - Nigeria and World News," accessed May 12, 2020, https://guardian.ng/news/kaduna-government-to-pay-dailyallowance-to-covid-19-frontline-health-workers/. medication he was given was malaria medication. People with other symptoms are turned into COVID -19 patients to add to the index number. This has instead ignited fear, which seems to kill more than the virus itself. Dokpesi questioned, "when has malaria become synonymous with COVID-19” (BEN Television, 2020). Similarly, another survey alleged that medical institutions are looking for every means to increase the index number of COVID19 victims. It is claimed that:

The Nigeria Center for Disease Control (NCDC) has instructed some medical personnel to declare any serious medical issue in their hospital as a COVID-19 case, which goes with a promise of incentives. Nurses or doctors who report a client as COVID-19 get a weekly stipend. Any medical personnel who could inject and kill an older person and sign a fake death certificate on that patient collect a substantial amount for every adult death as a reward (You Have Covid-19 If You Visit the Hospital in Nigeria, 2020.).

Accordingly, an interview in Cross River State asserted that people were pressured to declare themselves COVID-19 patients to be given some money. People showed text messages alleging that they were to make the pronouncement and be given a considerable amount of money (ChannelsTV, 2020a). A lady from Delta State submitted that she was paid fifteen thousand Naira to lie that she had COVID-19 (Emmanuel Dudu, 2020). Consequently, Nigerians expressed concern and doubt, and many chose not to go to the hospitals for any medical treatment of any kind because of the ongoing COVID-19 fraud in Nigeria. These conspiracy theories suggested that some individuals or institutions were doing business with the pandemic and pursuing personal benefits. It was pathetic that while COVID-19 disease was real and killing people, some within Nigeria's political elites and stakeholders were taking advantage of the pandemic to exploit the situation for a business venture.

Furthermore, the Governor of Kogi State, Yahaya Bello, cried out of an analogous conspiracy, contending that conspiracy plans were to import cases of coronavirus into Kogi State through illicit means. The governor also asserted that there was an unholy conspiracy to declare COVID-19 in all states of the federation, which suggested the attempt to import the disease or report fictitious cases. All these the governor described as "pressure from interesting quarters" (Abdulaziz, 2020). The presidential task force was also accused of instilling fear in people and lacked synergy by all those concerned (Ikumi, 2020). Responsively, rather than take the COVID-19 pandemic seriously, Nigerians used humor and comedies out of the pandemic. ${ }^{2}$

\section{THE CONSPIRACY OF LOCKDOWN}

Another area that drew criticism on government response to the COVID-19 pandemic was the measures of lockdowns. Different nations reacted differently to the pandemic as ghost cities were shown on television with empty and stalked

\footnotetext{
${ }^{2}$ What Nigerians Are Doing With The COVID-19
}

Lockdown (ChannelsTv, 2020), accessed May 26, 2020, https://www.youtube.com/watch?v=nzXa0FdRulg; (Ukomadu, 2020) 
economies. In Nigeria, the issue appeared to be different. People seemed to have responded with mixed reactions. The economy was shattered, as there were no measures to stabilize the prices of commodities. Some argued that people were asked to stay at home while there were no adequate provisions for and other necessities for their survival. ${ }^{3}$

In an interview with the Governor of Cross River State, Professor Ben Ayade, the governor acclaimed that despite using his experience as a scientist and all strict measures taken and him, together with top government officials leading at the front line, yet, there was pressure to declare COVID-19 cases in Cross River (ChannelsTV, 2020-b). Ayade, in his examination of the Nigerian response to the pandemic, avowed:

The government was not customizing the action plan that reflected the situation and originality of Nigeria. As a nation, Nigeria could not just put money in the hands of companies for the production of test materials just because they wanted to test. Testing was only possible when it was suspicious that it called for such. Also, the test measures lacked credibility and reliability, and the COVID-19 was not related to diagnostic techniques since it was unknown "novel." Thus, to conduct one COVID-19 test on a person and declare the result positive required some basic science rules and not just performing a rapid test and saying a person was a COVID-19 patient. So far, every test conducted was presumptuous. Also, in the western world, there seemed to be a business filing against all of these. As a medical professional, to do such a thing was abuse to his educational attainability and as a scientist. Consequently, the fight against COVID-19 had gone economic-political, and without a doubt, Nigerians and Africans were exploited due to Africa's lube holes (ChannelsTV, 2020-b). Admittedly, the Nigerian response to the COVID-19 outbreak seemed to follow what could be described as "the west syndrome." By implication, the government had no adequate measures to handle its problem but followed what others were doing. Following the west does not adequately address the need and impact of the virus on Africans and Nigerians.

Furthermore, Nigerians accused their political elites of not responding to the pandemic at the right time. For instance, many lamented that while other nations were closing their borders and civic leaders were addressing their citizens and reassuring their safety, Nigerian borders were opened, and the presidency did not make any national broadcast that could help calm their anxiety until different stakeholders pressured the presidency (TV 360 Nigeria, 2020). Despite the outcry, the administration accused the widespread concerns of some Nigerians as cheap politics and drama of a selected few. ${ }^{4}$ These concerns questioned the credibility, government style, and the love that instituted authorities have for the citizens.

${ }^{3}$ COVID-19: Mixed Reactions Trail Lockdown Extension in Lagos | TV360 Nigeria (TV360, 2020), accessed May 26, 2020, https://www.youtube.com/watch?v=mKNTiWi77Q; (COVID-19 Lockdown Bites Lagos' Unemployed Youth, 2020)

This publication is licensed under Creative Commons Attribution CC BY http://dx.doi.org/10.29322/IJSRP.10.12.2020.p10892

\section{THE CONSPIRACY OF ECONOMIC RESPONSE AND SHARING OF PALLIATIVES}

The outbreak of the COVID-19 pandemic ignited a national response by individuals and different organizations and stakeholders. Banks, individuals, and wealthy Nigerians contributed a considerable amount of money to fight the epidemic (CNN, 2020). Responsively, many Nigerians expressed dismay and fear that these monies may not be used purposefully due to previous corruption experiences in the government sectors. ${ }^{5}$ Also, others describe the move by individual and non-governmental organizations as hypocritical. For instance, banks were at the forefront of contributing to the coffers of the federal government; however, it was to the detriment of their staff. Like in Access Bank, it was lamented that after donating millions of Naira, the bank staff was faced with salary cuts to curb job loss (Olurounbi, 2020). Also, the expression of worries by Nigerians and the donations made opened a new face of fire outbreaks in different government buildings. Some Nigerians ascribed these fire incidences as a conspiracy to hide the corrupt practices of some interested people in government and avoid accounting for the funds raised to fight the pandemic (Siteadmin, 2020).

Furthermore, the measures that were taken by the presidency to curtail the spread of the pandemic adopted the means for people to stay at home. This directive included keeping away from large gatherings and halting societies' economies, which ignited anguish and anxiety in people. Citizens were groaning under the weight of the lockdown due to frustration, boredom, and hunger. Also, the lockdown extensions were described as worse than coronavirus (BBC News, 2020). Consequently, the president announced the distribution of palliatives to areas like Lagos, Ogun, and Abuja. The sharing of government palliative and the measures adopted for delivering these palliatives was debunked and described as a scam by many Nigerians (Vanguard News, 2020).

In an interview conducted by 9 News Nigeria, Buba Galadima, one of the leading critic of the Buhari-led government, asserted that the federal government's claim of continuing with the school feeding program while schools were closed was fraudulent, which only make Nigerians look like fools. Galadima also said, "Tell me which children in your area that they give food to or show me one person who has received the N20,000 palliative. It is so surprising that Nigerians, especially the media, kept quiet in the face of all these" (Mbam, 2020).

Accordingly, a member of Nigeria's senate, Ndume, called for the disbandment of the federal aid committee who was in charge of the Humanitarian services. The committee was accused of fraud and that it lacked credibility. The senate member expressed disappointment on Nigeria's president Buhari for not disbanding the committee despite the outcry of many Nigerians (Haruna, 2020). However, in response, the government asked the

${ }^{4}$ ChannelsTV, "Presidency Explains Buhari’s Approach To Coronavirus - YouTube," accessed May 26, 2020, https://www.youtube.com/watch?v=aFhRI-uB91s.

${ }^{5}$ Salawu Abiodun and Owolabi Samson Toyosi Olugbenga, eds., Exploring Journalism Practice and Perception in Developing Countries (Hershey, PA: IGI Global, 2017), 14; (Izevbekhai, 2015) 
concerned senate member to provide evidence of fraud against the palliative committee (editor, 2020).

In Lagos, for instance, like other parts of Nigeria that were on total lockdown, many citizens described the government as insincere. These concerned Nigerians claimed that the process of sharing the palliative was politicized as the more significant portion of the palliative package was reserved for party members, which led to lawless activities and the outbreak of violence (Okon, 2020). Appropriately, the accusation of fraudulent response on palliatives drew the attention of Independent Corrupt Practices and other Related Offences Commission (ICPC), an arm of government that deals with corruption-related matters. The commission called on all Nigerians to report breaches or any corrupt practices concerning the palliatives (Oyero, 2020). Thus, the media has remained a powerful means that the federal government was confronted to respond to the concerns of Nigerians rightly.

\section{THE IMPACT OF GOVERNMENT CONSPIRACY RESPONSE TO COVID-19 PANDEMIC ON NATIONAL DEVELOPMENT}

Before the global outbreak of COVID-19, Nigeria has battled with a fragile economy, insecurity, kidnapping, Boko Haram, and religious tensions. There are also political instability, underdevelopment, ethno-religious divisions, and demographic tensions between the predominantly educated Christian south and the mostly uneducated Muslim north. ${ }^{6}$ These diverse challenges have continued to threaten the peace, unity, and stability of the nation. The wake of the pandemic unearthed Nigeria's poor governance and laid bare the political brouhaha of the elite class. For instance, Nigeria's weak capacity of the health care infrastructure seemed to exacerbate the pandemic and its impact on national economies (Ekeruche, 2020).

Also, the epidemic has unraveled the negative impact of the Almajiri system of education in northern Nigeria. Accordingly, different states have struggled to maintain a basic standard of healthcare expectations; however, in northern Nigeria, an attempt was made to relocate thousands of Almajirai to other states of the federation without the consent of some governors, especially in the Middle Belt and the South. Consequently, several governors rejected these Almajirai and returned them, considering them as economic and social burdens, which has raised concern among northern leaders (Channels Television, 2020). In Kaduna, for instance, the government contended that twenty-one out of the sixty-one Almajirai received from Kano were tested positive for COVID-19, which is a threat to the already fragile health infrastructure (Anyaogu, 2020).

Meanwhile, in other parts of the country - South-South, South-East, and Middle Belt, the transfer of the Almajirai to their regions were unwelcomed. It was considered with high suspicion and described a conspiracy to invade their territories with an Islamization plan, more so that it was an attempt to take the fight of Boko Haram insurgency to their regions. Indeed, the joint

${ }^{6}$ Monica Emmanuel, Federalism in Nigeria: Between Divisions in Conflict and Stability in Diversity (Indonesia: Globethics.net, 2016); (David et al., 2015, p. 100) statement of leaders of the Southern and Middle Belt Forum (SMBLF) described the silence of the federal government and security organizations as worrisome and ominous (Johnson et al., 2020). Indeed, the deliberate dispatched of Almajirai to the Southern part of Nigeria amid curfew, inter-travel ban, and without due consultation with governors of these regions confirmed the suspicions of some Nigerians. It also raised tensions between the north and the south, thereby threatening the nation's peace, unity, and stability (Bodeemen, 2020).

The global outbreak of COVID-19 has the potential to wreak havoc in the fragility of Nigeria and trigger widespread unrest. It could also create economic and political tensions between regions. However, at the center of the conspiracy response to the COVID19 pandemic was the gross impact upon the ordinary citizen on the street of Nigeria. Unscrupulous leaders seemed to exploit the epidemic for their political and economic objectives to exacerbate crises among rival religions, rival communities, and geopolitical regions. Therefore, it was vital that the government re-strategize its approach to issues that affect the people and propose developmental measures that could help build the confidence of the citizens.

\section{THE TASK BEFORE THE NIGERIAN GOVERNMENT}

The coronavirus is a world-changing reality, and the aftermath could alter how the global society approached issues as things may never remain the same. The disease outbreak caught much of the world off guard that has surreal the ordinary life of societies (Colbert, 2020, p. 10). Indeed, the COVID-19 is described as the new age pandemic, whose speed and severity rivaled the 1918 influenza epidemic (Balasubramanian, 2020). It has stalked nations' economics, and like in Africa, and Nigeria in particular, the outbreak has paused challenge to the fragility of government infrastructural development, that had drawn national concerns (CENTRE, 2020).

Nigerians ought to rise and learn from the effects of the pandemic; this seems to be demonstrated by Ayade. Governor Ayade appeared to handle the COVID-19 epidemic in Cross Rivers differently from his other counterparts. His approach could provide Nigeria with a roadmap to deal with the country's issues differently. His COVID-19 response has been applauded both by the NCDC and the federal government (NseAbasi, 2020). The governor avers that Nigeria and Africa need to come out from a "follow the west syndrome" and think beyond the "stomach syndrome." By implication, the continent should be bold to address her unique issues, as did Madagascar, who did not wait for any approval from anyone. ${ }^{7}$

Similarly, Nigeria needs to set up a proper vaccine production plant, which could be the first of its kind (Published, 2020). Nigeria is a nation full of potential, brilliant, energetic, and hardworking people. The government can produce almost everything, and what the country with the wealth of professionalism requires is empowerment (T \& Nkechiny, 2019,

\footnotetext{
${ }^{7}$ Published, “Ayade's Anti-COVID-19 War Strategy
} Stirs Controversy," Punch Newspapers, 2020., accessed May 26, 2020, https://punchng.com/ayades-anti-covid-19-war-strategystirs-controversy/. 
p. 26). Arguably, Nigerians can lock their borders to viruses and other external threats and lock down the solutions.

Unfortunately, many Nigerians have expressed concern about the unwillingness of the government to invest in human capacity building. Also, Nigerian universities are disappointed and feel betrayed by the government for undermining their capabilities (Acemoglu \& Robinson, 2012). For example, despite the national cry by some stakeholders and the association of Nigerian medical doctors not to bring foreign medical personnel, the government went on to bring Chinese doctors, which received mixed reactions. ${ }^{8}$ It was later discovered that the so-called Chinese doctors were not all doctors, and their whereabouts seemed unknown (Ajayi, 2020). What Nigeria needs is human development that aims to increase knowledge, skills, and capacities in all sectors and all people. Nigerians need to be given adequate support and access to resources to enhance capacity building.

\section{CONCLUSION}

The making and the destruction of every society depend on the models that instituted authorities adopt in responding to issues that threaten the people it claimed to govern. It is delineating that some measures taken by the Nigerian government to curb the spread of COVID-19 were in collocation to the viewpoint of some Nigerians. Many ordinary Nigerians took to the media to express their dismay, including some political elites. Therefore, the government must explore measures to redress its citizenry's concerns swiftly. This calls for a collaborative and dialogical approach immersed in the national agenda, which seeks to promot the unity, peace, and stability of Nigeria's democracy.

\section{REFERENCES}

[1] Abdulaziz, A. (2020, 5 May). There's pressure to declare COVID-19 in KogiState Govt. https://www.premiumtimesng.com/regional/northcentral/391454-theres-pressure-to-declare-covid-19-in-kogi-state-govt.html

[2] Abiodun, S., \& Samson, O., Toyosi Olugbenga (Eds.). (2017). Exploring Journalism Practice and Perception in Developing Countries. IGI Global.

[3] Acemoglu, D., \& Robinson, J. A. (2012). Why Nations Fail: The Origins of Power, Prosperity and Poverty. Profile Books.

[4] Adeboyejo, A. (2020, 14 April). How Covid-19 Lockdowns Affect Healthcare of Non-Covid Cases. African Arguments. https://africanarguments.org/2020/04/14/how-covid-19-lockdowns-affecthealthcare-of-non-covid-cases/

[5] AfricaNews. (2020, 21 May). Madagascar to sign confidentiality clause with WHO On COVID-Organics. Africanews. https://www.africanews.com/2020/05/21/madagascar-prez-dismisses-allcritics-would-they-doubt-european-cure/

[6] Ajayi, O. (2020, 14 May). Stop Asking me about Chinese Doctors, Minister of Health tells Nigerians. Vanguard News. https://www.vanguardngr.com/2020/05/stop-asking-me-about-chinesedoctors-minister-of-health-tells-nigerians/

${ }^{8}$ Lawrence P. Patrick, "Bringing Chinese Doctors to Nigeria Is against National Interests - Reps Minority Caucus," Vanguard News, April 7, 2020, accessed May 26, 2020, https://www.vanguardngr.com/2020/04/bringing-chinesedoctors-to-nigeria-is-against-national-interests-reps-minoritycaucus/; Tofe Ayeni, "Nigerian Medical Association and Government Still Feuding," The Africa Report.Com, last
[7] Akinterinwa, B. A. (2020, 3 May). Nigeria: COVID-19 Pandemic and Nigeria-China Relations - Critical Issues and China's International Responsibility (I). https://allafrica.com/stories/202005030067.html

[8] Akpojivi, U. (2018). Media Reforms and Democratization in Emerging Democracies of Sub-Saharan Africa. Springer.

[9] Alfa Shaban, A. R. (2020, 22 April). COVID-organics: Madagascar launches Africa's first cure for virus. Africanews. https://www.africanews.com/2020/04/22/covid-organics-madagascarlaunches-africa-s-first-cure-for-virus/

[10] Ankara. (2020). COVID-19: Nigerian doctors oppose Chinese team's visit. Retrieved 26 May, 2020, from https://www.aa.com.tr/en/africa/covid-19nigerian-doctors-oppose-chinese-teams-visit/1794073

[11] Anyaogu, I. (2020, 2 May). 21 out of 61 Almajiris returned to Kaduna tested positive for COVID-19 -El Rufai. Businessday NG. https://businessday.ng/coronavirus/article/21-out-of-61-almajiris-returnedto-kaduna-tested-positive-for-covid-19-el-rufai/

[12] Avenue, H. R. W. |350 F. (2020, 14 April). Nigeria: Protect Most Vulnerable in COVID-19 Response. Human Rights Watch. https://www.hrw.org/news/2020/04/14/nigeria-protect-most-vulnerablecovid-19-response

[13] Ayeni, T. (2020, 15 April). Nigerian Medical Association and government still feuding. The Africa Report.Com. https://www.theafricareport.com/26172/coronavirus-nigerian-medicalassociation-and-government-still-feuding/

[14] Balasubramanian, M. (2020). Covid 19â-The New Age Pandemic. Notion Press.

[15] BBC News. (2020, 31 March). Lagos lockdown: "How will my children survive?" BBC News. https://www.bbc.com/news/world-africa-52093343

[16] BEN Television. (2020). DAAR GROUP, AIT Founder Dr. Raymond Dokpesi shares his Covid-19 experience. Retrieved 26 May, 2020, from https://www.youtube.com/watch?v=T8P-xbrZKq0

[17] Bodeemen. (2020, 16 May). Covid-19: Politics of Almajiri North to South Movement. https://www.blueprint.ng/covid-19-politics-of-almajiri-north-tosouth-movement/

[18] Cambell, J., \& McCaslin, J. (2020). How Nigeria Has Responded to COVID19 So Far. Council on Foreign Relations. Retrieved 12 May, 2020, from https://www.cfr.org/blog/how-nigeria-has-responded-covid-19-so-far

[19] CENTRE, T. T. L. (2020, 6 April). Impact of the Coronavirus (COVID-19) on the African Economy. Tralac. https://www.tralac.org/news/article/14483impact-of-the-coronavirus-covid-19-on-the-african-economy.html

[20] Channels Television. (2020, 11 May). Almajiri Evacuation, Rejection Causing Ripples. ChannelsTv. https://www.youtube.com/watch?v=ENOM6TebbEI

[21] ChannelsTV. (2020-a). Presidency Explains Buhari's Approach To Coronavirus-YouTube. Retrieved 26 May, 2020, from https://www.youtube.com/watch?v=aFhRI-uB9ls

[22] ChannelsTV. (2020-b). Why Cross River Is COVID-19 Free - Ayade Channels Television. Retrieved 26 May, 2020, from https://www.channelstv.com/2020/05/21/why-cross-river-is-covid-19-freeayade/

[23] ChannelsTV. (2020a, April 30). Cross River State Alleges Pressure From NCDC Over Testingâ-YouTube. https://www.youtube.com/watch?v=TmShytdorCY

[24] ChannelsTV. (2020b, 21 May). Why Cross River Has Not Recorded Any COVID-19 https://www.youtube.com/watch?v=vGvmm2wh5-w

[25] Chiefe, U. (2020, 10 March). How government and civil societies fought against the Social Media Bill. Techpoint.Africa. https://techpoint.africa/2020/03/10/nigeria-social-media-bill-hearing/

modified April 15, 2020, accessed May 26, 2020, https://www.theafricareport.com/26172/coronavirus-nigerianmedical-association-and-government-still-feuding/; Ankara, "COVID-19: Nigerian Doctors Oppose Chinese Team's Visit," accessed May 26, 2020, https://www.aa.com.tr/en/africa/covid19-nigerian-doctors-oppose-chinese-teams-visit/1794073; (Akinterinwa, 2020) 
[26] CNN, A. S. (2020). Government, banks and wealthy individuals contribute billions to fight coronavirus in Nigeria. CNN. Retrieved 26 May, 2020, from https://www.cnn.com/2020/03/27/africa/coronavirus-nigeriafund/index.html

[27] Colbert, D. (2020). Pandemic Protection: Safe, Natural Ways to Prepare Your Immune System Before You Need It. Charisma Media.

[28] COVID-19 lockdown bites Lagos' unemployed youth. (2020, 10 April). Africa News. https://www.youtube.com/watch?v=tUEjDlixl0U

[29] COVID-19: Mixed reactions trail lockdown extension in Lagos | TV360 Nigeria. (2020). TV360. Retrieved 26 May, 2020, from https://www.youtube.com/watch?v=mKNTiW-i77Q

[30] David, O. J., Asuelime, L. E., \& Onapajo, H. (2015). Boko Haram: The Socio-Economic Drivers. Springer.

[31] Denton, F. (2020, 27 April). Will COVID-19 leave fuel-rich African countries gasping for breath? International Institute for Environment and Development. https://www.iied.org/will-covid-19-leave-fuel-rich-africancountries-gasping-for-breath

[32] editor. (2020, 17 April). Provide Evidence of Fraud against Palliative Committee, Presidency Tells Ndume. THISDAYLIVE https://www.thisdaylive.com/index.php/2020/04/17/provide-evidence-offraud-against-palliative-committee-presidency-tells-ndume/

[33] Ekeruche, C. O. and M. A. (2020, 8 April). Understanding the impact of the COVID-19 outbreak on the Nigerian economy. Brookings. https://www.brookings.edu/blog/africa-in-focus/2020/04/08/understandingthe-impact-of-the-covid-19-outbreak-on-the-nigerian-economy

[34] Ekonde, D. (2020). The challenge with African countries promoting traditional cures for Covid-19 without research. Quartz Africa. Retrieved 12 May, 2020, from https://qz.com/africa/1852069/african-countries-want-toboost-traditional-cures-for-covid-19/

[35] Elumoye, D., \& Okocha, C. (2020, 10 April). Nigeria: SGF Laments Nigeria's Poor Health Infrastructure. AllAfrica.Com. https://allafrica.com/stories/202004100301.html

[36] Emmanuel Dudu, N. (2020). (9) 9news Nigeria - Facebook Search. Retrieved 26 May, 2020, from https://web.facebook.com/search/top/?q=9news\%20nigeria\&epa=SEARCH _BOX

[37] Emmanuel, M. (2016). Federalism in Nigeria: Between Divisions in Conflict and Stability in Diversity. Globethics.net.

[38] Fitch, B. D. (Ed.). (2013). Law Enforcement Ethics. SAGE.

[39] Gate, B. (2020, 13 April). Bill Gates on Finding a Vaccine for COVID-19, the Economy, and Returning to 'Normal Life.' TheEllenShow.

[40] H, O., Oseloka. (2017). Prime Witness: Change and Policy Challenges in Buhariís Nigeria. Safari Books Ltd.

[41] Haruna, A. (2020, 17 April). Nigeria: Coronavirus - Senator Accuses Federal Aid Committee of Fraud, Calls for Disbandment. AllAfrica.Com. https://allafrica.com/stories/202004170085.html

[42] Idris, Sani. (2020, 22 March). COVID -19: Kaduna residents express fear over total lockdown. NNN NEWS NIGERIA. https://nnn.com.ng/covid-19kaduna-residents-express-fear-over-total-lockdown/

[43] Ikumi, T. (2020). "I Was Left In The Ambulance For Two Hours," COVID19 Survivor Narrates Ordeal. ChannelsTv. Retrieved 26 May, 2020, from https://www.youtube.com/watch?v=jpjRmEGxBk4

[44] INSIGHT: Covid-19 Pandemic - Nigeria's Fiscal and Economic Measures. (2020). Retrieved 12 May, 2020, from https://news.bloombergtax.com/dailytax-report-international/insight-covid-19-pandemic-nigerias-fiscal-andeconomic-measures

[45] Izevbekhai, M. (2015). Strategies for Sustainable Transformation of Developing Countries: A Road Map for a Sustainable Developed Nigeria. AuthorHouse.

[46] Johnson, D., Onoyume, J., Ahon, F., Yakubu, D., \& Ajayi, O. (2020, 11 May). Nigeria: COVID-19 - Southern, M-Belt Leaders Raise Alarm Over $\begin{array}{llll}\text { Invasion } & \text { By }\end{array}$ https://allafrica.com/stories/202005110462.html

[47] Junior, U. O. (2013). Patriotism Has No Party: Defining Democracy Within the Context of Ensuring Peace. Xlibris Corporation.

[48] Lennox, J. (2020). Where is God in a Coronavirus World? The Good Book Company.

[49] Mahbubani, K. (2020). Has China Won?: The Chinese Challenge to American Primacy. PublicAffairs.
[50] Mbam, U. (2020, 24 May). COVID-19: "FG's N20k Cash Transfer, Schoo Feeding Program A Fraud" - Buba Galadima Reveals. 9News Nigeria. https://9newsng.com/covid-19-fgs-n20k-cash-transfer-school-feedingprogram-a-fraud-buba-galadima-reveals/

[51] Nigeria-KPMG Global. (2020, 11 May). KPMG https://home.kpmg/xx/en/home/insights/2020/04/nigeria-government-andinstitution-measures-in-response-to-covid.html

[52] Nigerians React To President Buhari's Speech On Covid-19-YouTube (n.d.). Retrieved 26 May, 2020, from https://www.youtube.com/watch?v=KISepHpqjM

[53] NseAbasi, N. (2020). Ayade Vs. Covid 19:a Fight To Finish! Nigerian Voice. Retrieved 26 May, 2020, from https://www.thenigerianvoice.com/news/288188/ayade-vs-covid-19a-fightto-finish.html

[54] Okon, D. (2020, 19 April). Lamentation still trails Lagos, FG's palliative package as middlemen hijack programme. Businessday NG. https://businessday.ng/features/article/lamentation-still-trails-lagos-fgspalliative-package-as-middlemen-hijack-programme/amp/

[55] Okorie, N., Raphael, O., Babatunde, \& Abiodun, S. (Eds.). (2016). Impacts of the Media on African Socio-Economic Development. IGI Global.

[56] Olabode, S. A. (2018). Digital Activism and Cyberconflicts in Nigeria: Occupy Nigeria, Boko Haram and MEND. Emerald Group Publishing.

[57] Olurounbi, R. (2020, 5 May). Nigeria's Access Bank announces salary cuts to curb job loss. The Africa Report.Com. https://www.theafricareport.com/27379/coronavirus-nigerias-access-bankannounces-salary-cuts-to-curb-job-loss/

[58] Omotoso, 'Femi, \& Kehinde, M. (Eds.). (2016). Democratic Governance and Political Participation in Nigeria 1999-2014. Spears Media Press.

[59] Owolabi, F. (2020, 28 May). PTF: Abandoning patients with other illnesses over COVID-19 scare has led to more deaths. TheCable. https://www.thecable.ng/ptf-abandoning-patients-with-other-illnesses-overcovid-19-scare-has-led-to-more-deaths

[60] Oyero, K. (2020). Lockdown: Report fraud in FG's cash transfer, ICPC tells Nigerians. Punch Newspapers. Retrieved 26 May, 2020, from https://punchng.com/lockdown-report-fraud-in-fgs-cash-transfer-icpc-tellsnigerians/

[61] Ozugbakun, A. (2020). Community transmission fuels the rise in COVID-19 Cases in Nigeria-YouTube. Retrieved 25 May, 2020, from https://www.youtube.com/watch?v=wo3EHFonO6s

[62] P. Patrick, L. (2020, 7 April). Bringing Chinese doctors to Nigeria is against national interests - Reps minority caucus. Vanguard News. https://www.vanguardngr.com/2020/04/bringing-chinese-doctors-tonigeria-is-against-national-interests-reps-minority-caucus/

[63] Published. (2020). Ayade's anti-COVID-19 war strategy stirs controversy. Punch Newspapers. Retrieved 26 May, 2020, from https://punchng.com/ayades-anti-covid-19-war-strategy-stirs-controversy/

[64] Siteadmin. (2020, 18 April). Nigerians Express Concern As 'Mysterious Fire' Consumes Three Government Offices In Abuja Under 10 Days [Text]. Sahara Reporters. http://saharareporters.com/2020/04/18/nigerians-expressconcern-\%E2\%80\% 98mysterious-fire\%E2\%80\%99-consumes-threegovernment-offices-abuja-under

[65] T, O., Mutiat, \& Nkechiny, O.-U. (Eds.). (2019). Social Protection in Africa: A Study of Paradigms and Contexts. Reamsworth Publishing.

[66] TV 360 Nigeria. (2020). Senate wants Buhari to address the nation on COVID-19 | TV360 Nigeria-YouTube. Retrieved 26 May, 2020, from https://www.youtube.com/watch?v=_NJIcBfvbHA

[67] TVCNews. (2020). Naira Devaluation: Financial expert explains impact on the economy | TV360 Nigeria-YouTube. Retrieved 25 May, 2020, from https://www.youtube.com/watch?v=ItFNfR3kp40

[68] Ukomadu, A. (2020, 11 May). Nigerian comics fight COVID-19 with gags and slapstick slaps. Reuters. https://www.reuters.com/article/us-healthcoronavirus-nigeria-comedy-idUSKBN22K1LI

[69] Unah, L. (2020, 14 April). Nigerian private sector donates more than most other African countries in fight against COVID-19. African Business Magazine. https://africanbusinessmagazine.com/sectors/healthsectors/covid-19/nigerian-private-sector-donates-more-than-most-otherafrican-countries-in-fight-against-covid-19/

[70] Vanguard News. (2020, 16 April). Lockdown palliative a scam, residents fume. Vanguard News. https://www.vanguardngr.com/2020/04/lockdownpalliative-a-scam-residents-fume/ 
[71] Vinson, L. T. (2017). Religion, Violence, and Local Power-Sharing in Nigeria. Cambridge University Press.

[72] Warah, R. (2020, 15 May). What COVID-19 Has Revealed About Our Callous and Clueless Leaders. https://www.theelephant.info/opeds/2020/05/15/what-covid-19-has-revealed-about-our-callous-andclueless-leaders/

[73] What Nigerians Are Doing With The COVID-19 Lockdown. (2020). ChannelsTv. Retrieved 26 May, 2020, from https://www.youtube.com/watch?v=nzXa0FdRulg

[74] WHO Director-General's opening remarks at the media briefing on COVID19-11 March 2020. (2020). Retrieved 21 March, 2020, from https:/www.who.int/dg/speeches/detail/who-director-general-s-openingremarks-at-the-media-briefing-on-covid-19---11-march-2020
[75] Why Nigeria reduce fuel price from N145. (2020, 18 March). BBC News Pidgin. https://www.bbc.com/pidgin/tori-51946591

[76] You have Covid-19 if you visit the hospital in Nigeria. (2020). Retrieved 26 May, 2020, from https://www.youtube.com/watch?v=GGTEQVgnd5s

\section{AUTHORS}

First Author - Henry Marcus Garba, Africa International University, Department of Historical Studies +254755694957 henrymarcusg81@gmail.com 